Graphical Abstract

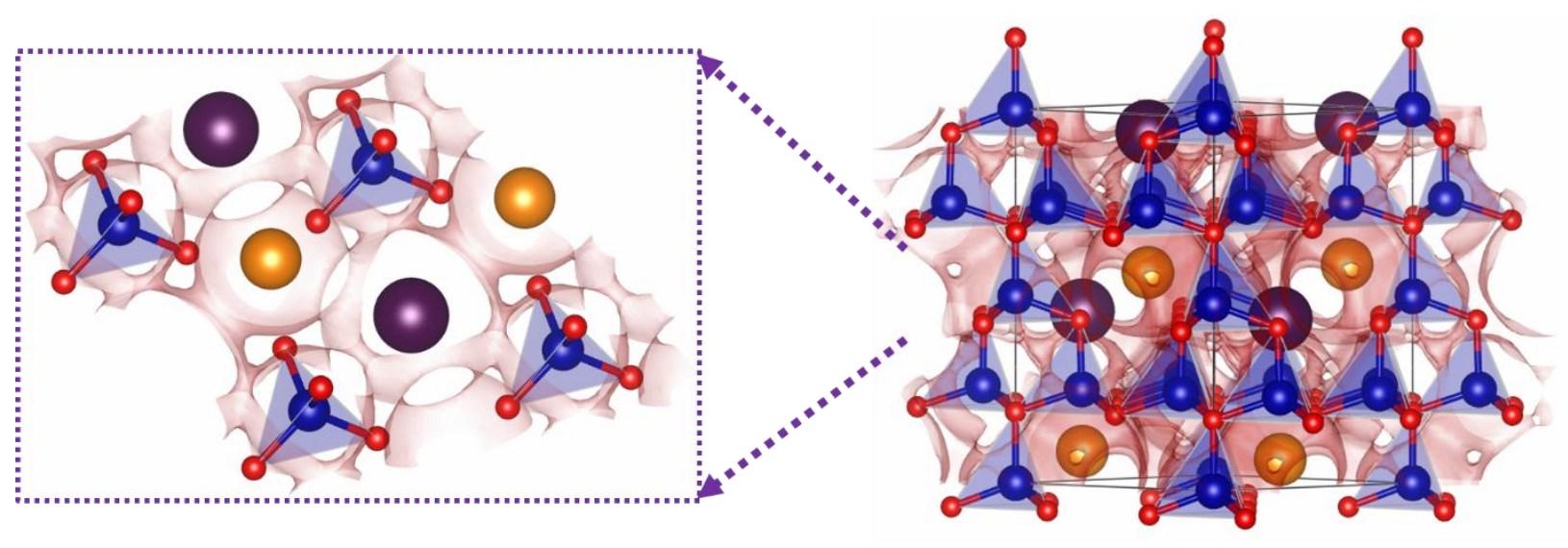




\title{
Unravelling the low thermal expansion coefficient of cation-substituted $\mathrm{YBaCo}_{4} \mathrm{O}_{7+\delta}$
}

\author{
Wang Hay Kan, ${ }^{1}$ Ke-Yu Lai, ${ }^{1}$ Ashfia Huq, ${ }^{2}$ and Arumugam Manthiram ${ }^{1, *}$ \\ ${ }^{1}$ Electrochemical Energy Laboratory, Materials Science and Engineering Program, The \\ University of Texas at Austin, Austin, TX, USA. \\ ${ }^{2}$ Neutron Scattering Science Division, Oak Ridge National Laboratory, Oak Ridge, TN, USA \\ Wang Hay Kan: jackkan.chem@gmail.com Ke-Yu Lai: keyulai@utexas.edu \\ Ashfia Huq: huqa@ornl.gov

\section{Arumugam Manthiram: rmanth@mail.utexas.edu}

\begin{abstract}
With an aim to understand the origin of the low thermal expansion coefficients (TECs), cation-substituted $\mathrm{YBaCo}_{4} \mathrm{O}_{7}$-type oxides have been investigated by in-situ neutron diffraction, bond valence sum (BVS), thermogravimetic analysis, and dilatometry. The compositions $\mathrm{YBaCo}_{3} \mathrm{ZnO}_{7+\delta}, \mathrm{Y}_{0.9} \mathrm{In}_{0.1} \mathrm{BaCo}_{3} \mathrm{ZnO}_{7+\delta}$, and $\mathrm{Y}_{0.9} \mathrm{In}_{0.1} \mathrm{BaCo}_{3} \mathrm{Zn}_{0.6} \mathrm{Fe}_{0.4} \mathrm{O}_{7+\delta}$ were synthesized by solid-state reaction at $1200{ }^{\circ} \mathrm{C}$. Rietveld refinement of the joint synchrotron X-ray and neutron diffraction data shows that the $\mathrm{Zn}$ and Fe dopants have different preferences to substitute the Co ions in the $6 c$ and $2 a$ sites. The bulk thermal-expansion coefficient of $\mathrm{YBaCo}_{3} \mathrm{ZnO}_{7+\delta}$, $\mathrm{Y}_{0.9} \mathrm{In}_{0.1} \mathrm{BaCo}_{3} \mathrm{ZnO}_{7+\delta}$, and $\mathrm{Y}_{0.9} \mathrm{In}_{0.1} \mathrm{BaCo}_{3} \mathrm{Zn}_{0.6} \mathrm{Fe}_{0.4} \mathrm{O}_{7+\delta}$ are, respectively, 9.42, 9.76, and $9.06 \mathrm{x}$ $10^{-6}{ }^{\circ} \mathrm{C}^{-1}$. Neutron diffraction data show that the low anisotropic TEC along the $a$-axis is the main contributor to the low bulk TECs. With the substitution of $\mathrm{In}, \mathrm{Zn}$, and $\mathrm{Fe}$ in $\mathrm{Y}_{0.9} \mathrm{In}_{0.1} \mathrm{BaCo}_{3} \mathrm{Zn}_{0.6} \mathrm{Fe}_{0.4} \mathrm{O}_{7+\delta}$, the anisotropic and bulk TECs could be reduced to 8.94 and $9.06 \mathrm{x}$ $10^{-6}{ }^{\circ} \mathrm{C}^{-1}$, respectively, mainly due to the suppression of the change in $\mathrm{Co}-\mathrm{O}$ bond length in $\mathrm{CoO}_{4}$ polyhedra. The observed weight loss during heating is due to the loss of interstitial oxide ions, as revealed by neutron diffraction and BVS map. $\mathrm{Y}_{0.9} \mathrm{In}_{0.1} \mathrm{BaCo}_{3} \mathrm{Zn}_{0.6} \mathrm{Fe}_{0.4} \mathrm{O}_{7+\delta}$ has the lowest areaspecific cathodic polarization resistance of $0.14 \mathrm{ohm} \mathrm{cm}^{2}\left(\mathrm{R}_{\text {total }} / 2\right)$ at $700{ }^{\circ} \mathrm{C}$ in air.
\end{abstract}

Keywords: cation-substituted $\mathrm{YBaCo}_{4} \mathrm{O}_{7}$, neutron diffraction, thermal expansion coefficient

* To whom correspondence should be addressed.

Phone: (512) 471-1791. Fax: (512) 475-8482. E-mail: rmanth@mail.utexas.edu (A. Manthiram) 


\section{Introduction}

Solid oxide fuel cells (SOFCs) are promising energy conversion devices with superior combined electric and heat efficiency (> 90\%) [1,2]. Low-cost electricity can be generated by employing abundant hydrocarbon fuels (e.g., methane). Bloom energy and Redox energy in the US are developing energy servers (e.g., for Google and Microsoft) with conventional SOFC technology to provide reliable electricity [3, 4]. The state-of-the-art SOFCs are composed of $\mathrm{La}_{0.65} \mathrm{Sr}_{0.3} \mathrm{MnO}_{3}, \mathrm{Y}_{0.16} \mathrm{Zr}_{0.84} \mathrm{O}_{1.92}$, and $\mathrm{Ni}-\mathrm{Y}_{0.16} \mathrm{Zr}_{0.84} \mathrm{O}_{1.92}$ as cathode, electrolyte, and anode, respectively [2]. However, such cells require high operating temperatures $\left(800-1000{ }^{\circ} \mathrm{C}\right)$ to catalyze the electrochemical reactions occurring on the triple-phase boundary (TPB). Lowering the operating temperature to $600-800{ }^{\circ} \mathrm{C}$ is the key to reducing the cost in term of materials choice, cell-degradation, and redox-tolerance [2].

In the intermediate temperature range $\left(500-800{ }^{\circ} \mathrm{C}\right)$, the electrochemical reduction of oxygen molecule on the cathode is sluggish as the polarization resistance of $\mathrm{La}_{0.65} \mathrm{Sr}_{0.3} \mathrm{MnO}_{3}$ (LSM) increases exponentially with decreasing temperature [5]. Alternative materials with higher catalytic activities have been reported in the last decade, including $\mathrm{Ba}_{0.5} \mathrm{Sr}_{0.5} \mathrm{Co}_{0.8} \mathrm{Fe}_{0.2} \mathrm{O}_{3-\delta}$

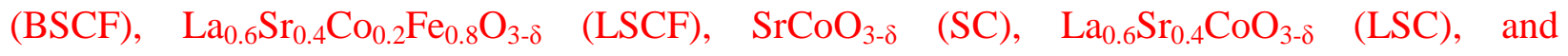
$\mathrm{YBaCo}_{4} \mathrm{O}_{7+\delta}(\mathrm{YBC})[6,7]$. In particular $\mathrm{YBaCo}_{4} \mathrm{O}_{7+\delta}$ is of great interest due to its low thermalexpansion coefficient (TEC), which matches well with oxide-ion conducting electrolytes, such as $\mathrm{Y}_{0.16} \mathrm{Zr}_{0.84} \mathrm{O}_{1.92}$ (YSZ), $\mathrm{Gd}_{0.1} \mathrm{Ce}_{0.9} \mathrm{O}_{1.95}$ (GDC), and $\mathrm{La}_{0.8} \mathrm{Sr}_{0.2} \mathrm{Ga}_{0.8} \mathrm{Mg}_{0.2} \mathrm{O}_{3-\delta}$ (LSGM) (Fig. 1) [8, 9]. A large TEC mismatch between the cathode and the electrolyte can lead to delamination of the electrode material from the electrolyte when the cells undergo thermal cycling [10]. 
Tsipis et al. first reported the use of $\mathrm{YBaCo}_{4} \mathrm{O}_{7+\delta}$ and its Fe-doped derivate as SOFC cathodes; their cells had a low overpotential $(6.9 \mathrm{mV})$ at $150 \mathrm{~mA} \mathrm{~cm}{ }^{-2}$ at $800{ }^{\circ} \mathrm{C}$ [11], but the samples were found to decompose on keeping at elevated temperatures for long time. As similar to other metal oxides (e.g., perovskite) $[12,13]$, the chemical stability of $\mathrm{YBaCo}_{4} \mathrm{O}_{7+\delta}$ could be tailored by doping. Valldor et al. found that $\mathrm{YBaCo}_{4} \mathrm{O}_{7+\delta}$-type oxides have a large solubility for dopants and $\mathrm{RBaM}_{4} \mathrm{O}_{7+\delta}(\mathrm{R}=\mathrm{Ca}, \mathrm{Y}, \mathrm{In}, \mathrm{Dy}-\mathrm{Lu}, \mathrm{M}=\mathrm{Co}, \mathrm{Al}, \mathrm{Zn}$, and Fe) could be prepared by solid-state synthesis [14]. Our group explored the substitution of $\mathrm{In} / \mathrm{Ca}$ for $\mathrm{Y}$ ions in $\mathrm{YBaCo}_{3} \mathrm{ZnO}_{7+\delta}$ as $\mathrm{SOFC}$ cathodes $[15,16]$. Vert et al. reported $\mathrm{TbBaCo}_{3} \mathrm{ZnO}_{7+\delta}$ to have area specific resistance of $30 \mathrm{~m} \Omega \quad \mathrm{cm}^{2}$ at $850{ }^{\circ} \mathrm{C}$ [17]. Our group also reported $\mathrm{Y}_{0.5} \mathrm{Ca}_{0.5} \mathrm{BaCo}_{2.5} \mathrm{Zn}_{1.5} \mathrm{O}_{7+\delta}$ and related compounds to have good electrochemical performance, low TEC, and chemical stability [18-21]. A maximum power density of $450 \mathrm{~mW} \mathrm{~cm}{ }^{2}$ at $700{ }^{\circ} \mathrm{C}$ was obtained with the anode supported single SOFC [18-21].

The above preliminarily studies have shown that cation-substititued $\mathrm{YBaCo}_{4} \mathrm{O}_{7+\delta}$ compounds might be suitable for SOFC cathodes. However, many suffer from poor thermal and/or chemical stability at elevated temperatures $\left(600-800{ }^{\circ} \mathrm{C}\right)$. For example undoped $\mathrm{YBaCo}_{4} \mathrm{O}_{7+\delta}$ decomposes into $\mathrm{Y}_{2} \mathrm{O}_{3}, \mathrm{BaO}$, and $\mathrm{CoO}_{\mathrm{x}}$ at $800{ }^{\circ} \mathrm{C}$ within hours [22]. Such a structural instability comes mainly from its open structure in which the polyhedra $\mathrm{YO}_{6}$ and $\mathrm{CoO}_{4}$ are connected with each other by corner-sharing. Isovalent dopants with small ionic radii can effectively reduce the metal and oxygen bond length $\mathrm{d}_{(\mathrm{M}-\mathrm{O})}$ in the $\mathrm{MO}_{4}$ and/or $\mathrm{MO}_{6}$ polyhedra due to the increase in effective nuclear charge [23-25]. Similarly, a stronger effect can also come from aliovalent doping with highly charged species in which both the dopant size and charge play important roles on controlling the bond strength and other physical properties, such as TEC [13]. Compounds with larger lattice energies usually have smaller TECs [26]. However, since the 
cation-substituted $\mathrm{YBaCo}_{4} \mathrm{O}_{7}$ compounds have a non-cubic crystal structure, their TEC could likely be anisotropic. This provides an excellent opportunity to study their isovalent and aliovalent doping effects. Moreover, the substitution of dopants for the Co ions as in $\mathrm{YBaCo}_{3} \mathrm{ZnO}_{7+\delta}$ can occur in either $6 c$ and/or $2 a$ sites, but their distributions have not been understood. It is also unclear if the oxide-ion conduction mechanism is due to oxide-ion vacancy formation or interstitial oxide-ion movement. In this paper, we use synchrotron X-ray, in-situ time of flight (TOF) neutron diffraction, thermogravimetic analysis (TGA), bond valence sum (BVS) map, and dilatometry to understand the origin of the low TEC of cation-substituted $\mathrm{YBaCo}_{4} \mathrm{O}_{7+\delta}$-type oxides. In addition, we focus on understanding the oxide-ion conduction mechanism at elevated temperatures and the impact of the dopant ions on the anisotropic TEC and on other structural properties. We choose $\mathrm{YBaCo}_{3} \mathrm{ZnO}_{7+\delta}, \mathrm{Y}_{0.9} \mathrm{In}_{0.1} \mathrm{BaCo}_{3} \mathrm{ZnO}_{7+\delta}$, and $\mathrm{Y}_{0.9} \mathrm{In}_{0.1} \mathrm{BaCo}_{3} \mathrm{Zn}_{0.6} \mathrm{Fe}_{0.4} \mathrm{O}_{7+\delta}$ to study as they show good chemical stability and low TEC. The investigation can enhance our fundamental understanding of the structure-property relationships of these complex oxides and help design high-performance cathode materials for SOFC.

\section{Experimental}

\subsection{Synthesis}

$\mathrm{YBaCo}_{3} \mathrm{ZnO}_{7+\delta}, \quad \mathrm{Y}_{0.9} \mathrm{In}_{0.1} \mathrm{BaCo}_{3} \mathrm{ZnO}_{7+\delta}$, and $\mathrm{Y}_{0.9} \mathrm{In}_{0.1} \mathrm{BaCo}_{3} \mathrm{ZnO}_{7+\delta}$ were synthesized by solid-state reaction. Stoichiometric amounts of $\mathrm{Y}_{2} \mathrm{O}_{3}, \mathrm{In}_{2} \mathrm{O}_{3}, \mathrm{BaCO}_{3}, \mathrm{Co}_{3} \mathrm{O}_{4}, \mathrm{ZnO}$, and $\mathrm{Fe}_{3} \mathrm{O}_{4}$ were ball-milled and heated first at $1000{ }^{\circ} \mathrm{C}$ for $12 \mathrm{~h}$. The resulting powders were ground, pelletized, and heat-treated again at $1200{ }^{\circ} \mathrm{C}$ for $24 \mathrm{~h}$. The final products were black powders. 


\subsection{Phase characterization}

Phases were identified by powder X-ray diffraction (PXRD) (Rigaku Ultima IV powder xray diffractometer, $\mathrm{Cu} \mathrm{K}_{\alpha}$ radiation, $40 \mathrm{kV}, 44 \mathrm{~mA}$ ) from $2 \theta=10^{\circ}$ to $80^{\circ}$ at a count rate of $10 \mathrm{~s}$ per step of $0.02^{\circ}$ at room temperature. Synchrotron X-ray diffraction was performed at ambient temperature from $2 \theta=0.5^{\circ}$ to $130^{\circ}$ with a $2 \theta$ step size of $0.0001^{\circ}$ using monochromatic X-ray $(\lambda$ $=0.4 \AA$ ) at the Advanced Photon Source (APS). The samples were packed into Kapton ${ }^{\circledR}$ Capillary Tube. In-situ time-of-flight neutron diffraction (ND) data were collected at the Oak Ridge National Laboratory (ORNL) Spallation Neutron Source (SNS) Powgen beamline using a beam of neutron with a center wavelength of $1.333 \AA$ A. The samples were packed into a quartz tube and the data were collected between 25 and $800{ }^{\circ} \mathrm{C}$ in air. The room temperature synchrotron X-ray and neutron datasets were joint-refined by the conventional Rietveld method using the General Structure Analysis System (GSAS) package with the graphical user interface (EXPGUI) [27]. The background, scale factor, zero-point position, absorption, cell parameters, atomic positions, thermal parameters and profile coefficients for Pseudo-Voigt / Finger, Cox, and Jephcoat (FCJ) Asymmetric peak shape function were refined until the convergence was achieved. In particular, all thermal parameters were treated as isotropic, except for $\mathrm{O}(1), \mathrm{O}(2)$ and $\mathrm{O}(3)$, which were considered as anisotropic. Bond lengths were obtained by Bond Distance and Angle Computation (DISAGL) Version Win32 Crystal Structure Distance and Angle Program in the GSAS [27]. The bond valences were calculated by Bond Valence Calculation and Listing (VaList) [28, 29]. The bond valence sum map was calculated by 3DBVSMAPPER.[30] Selected area electron diffraction (SAED) was measured with JEOL 2010F Transmission Electron Microscope. Bulk TECs were measured with a dilatometer (Linseis L75H) at a ramping rate of $3{ }^{\circ} \mathrm{C} \min ^{-1}$ between 30 and $900{ }^{\circ} \mathrm{C}$, and the relative density of bulk samples determined by 
Archimedes method were all more than $98 \%$ of the theoretical density (or less than $2 \%$ porosity).

The anisotropic TEC were obtained from the least-square fitting (Rietveld refinement) of the neutron diffraction data between 25 and $800{ }^{\circ} \mathrm{C}$. Bulk change in oxygen content was analyzed with the NETZSCH Jupiter STA 449 F3 thermogravimetric analyzer (TGA) where the sample was cooled down at $2{ }^{\circ} \mathrm{C} / \mathrm{min}$ from the sintering temperature. The heating profile for the TGA was same as the profile for the high-temperature neutron diffraction analysis. The initial oxygen content and the oxidation state of Co ions at room temperature were determined by iodometric titration [13].

\subsection{Electrochemical impedance spectroscopy}

The cathode materials were first ball-milled, mixed with the organic binder (Heraeus V006), screen-printed onto both sides of the $\mathrm{Ce}_{0.9} \mathrm{Gd}_{0.1} \mathrm{O}_{1.95}$ (GDC) supports, and sintered at $1000{ }^{\circ} \mathrm{C}$ for $2 \mathrm{~h}$. The Ag mesh and wire were attached to each electrode and the Ag paste was applied as the current collector. The electrochemical measurements using a 2-electrode half-cell were performed with a Solartron electrochemical impedance analyzer (SI model no. 1260, $10 \mathrm{mV}$, $0.01-1 \mathrm{MHz})$. The cell was heated to the temperature range of $500-800{ }^{\circ} \mathrm{C}$ within a tubular furnace (Barnstead; model no. 21100) and held at a given constant temperature for $2 \mathrm{~h}$ prior to each measurement. The equivalent circuit was fitted in $\mathrm{ZView}^{\mathrm{TM}}[31]$.

\section{Results and discussion}

\subsection{Structural analysis of cation-substituted $\mathrm{YBaCo}_{4} \mathrm{O}_{7}$}

The crystal structure of $\mathrm{YBaCo}_{4} \mathrm{O}_{7+\delta}$ was first determined by single $\mathrm{X}$-ray diffraction as a hexagonal unit cell with the space group of $P 6_{3} m c$ and cell parameters of $a=6.2982(4)$ and $c=$ 
10.2467(9) $\AA[22,32]$. Such a phase is isostructural to the non-magnetic $\mathrm{LuBaZn}_{3.09} \mathrm{Al}_{0.91} \mathrm{O}_{7+\delta}$ $[33,34]$, but is magnetic with mixed-valent $\mathrm{Co}^{2+/ 3+}$ ions at ambient condition. The Co ions are located at two different tetrahedral sites $(2 a$ and $6 c)$ of the oxygen lattice, corner-connected to form the triangular and Kagomé layers in 1:1 stacking along the $z$-axis. X-ray diffraction revealed that the $\mathrm{Co}-\mathrm{O}$ bond lengths were slightly shorter for Co ions at the $2 a$ sites than at the $6 c$ sites, resulting in a higher valence for Co ions at the $2 a$ site. A space group in the same crystallographic system but with a lower symmetry of P31c was also reported by Avci et al. for $\mathrm{YBaCo}_{4} \mathrm{O}_{7+\delta}$ using high-resolution synchrotron $\mathrm{X}$-ray diffraction and neutron data $[35,36]$. The diffraction patterns for the two different space groups $\left(\mathrm{P}_{3} \mathrm{mc}\right.$ and P31c) are almost identical at low $\mathrm{Q}$ range, but Avci and Huq pointed out that the patterns can only be fitted well with P31c for the high $\mathrm{Q}$ range data. Such an arrangement could improve the goodness of fit by reducing the unusually large thermal parameters of the $\mathrm{Co}(2), \mathrm{O}(1)$ and $\mathrm{O}(2)$ atoms in the structural solution with a space group of $P 6_{3} m c$.

In addition to the parent phase of $\mathrm{YBaCo}_{4} \mathrm{O}_{7+\delta}$, many cation-substituted $\mathrm{YBaCo}_{4} \mathrm{O}_{7+\delta}$ compounds have also been reported in the literature. For example, our group studied $\mathrm{YBaCo}_{3} \mathrm{ZnO}_{7+\delta}, \mathrm{Y}_{0.9} \mathrm{In}_{0.1} \mathrm{Co}_{3} \mathrm{ZnO}_{7+\delta}$, and $\mathrm{Y}_{0.9} \mathrm{In}_{0.1} \mathrm{Co}_{3} \mathrm{Zn}_{0.6} \mathrm{Fe}_{0.4} \mathrm{O}_{7+\delta}$ as low TEC cathodes for SOFCs in the intermediate temperature range $[15,16,18-21]$. However, the distributions of the dopants in the various crystallographic sites were not well understood as the dopants could have different preferences to stay at the $2 a$ and $6 c$ sites. The small differences between the atomic scattering factors of $\mathrm{Zn}, \mathrm{Co}$, and Fe make such analysis difficult using laboratory-based powder X-ray diffractometer [37]. Alternatively, we used the joint synchrotron X-ray and high resolution neutron data to study the structural details, cell parameters, and bond lengths as a function of temperature for the three cation-substituted $\mathrm{YBaCo}_{4} \mathrm{O}_{7+\delta}$ compounds above [38]. 
Rietveld refinement structural model for $\mathrm{YBaCo}_{3} \mathrm{ZnO}_{7+\delta}$ was constructed with the $P 31 c$ space group, as suggested by Huq [36]. A constrain was created such that the $\mathrm{Zn}$ ions can substitute for Co ions at the $2 a$ and $6 c$ sites. Since the multiplicity of the two positions are different, the change of $\mathrm{Zn}$ content at the $2 a$ site was offset by three times the change of $\mathrm{Zn}$ content in $6 c$ site. The $\mathrm{Co}$ and $\mathrm{Zn}$ atoms, which are located at the same crystallographic positions, are constrained to have the same coordination and thermal parameters. Structural model for $\mathrm{Y}_{0.9} \mathrm{In}_{0.1} \mathrm{Co}_{3} \mathrm{ZnO}_{7+\delta}$ and $\mathrm{Y}_{0.9} \mathrm{In}_{0.1} \mathrm{Co}_{3} \mathrm{Zn}_{0.6} \mathrm{Fe}_{0.4} \mathrm{O}_{7+\delta}$ were created similarly except $10 \%$ of $\mathrm{Y}$ ions were substituted by In ions at the $2 b$ site. All compounds, except $\mathrm{YBaCo}_{3} \mathrm{ZnO}_{7+\delta}$, could be well fitted with a single phase P31c structure; a second phase of P31c (20\%) but with a slightly larger unit cell volume (by $0.12 \%$ ) was required for $\mathrm{YBaCo}_{3} \mathrm{ZnO}_{7+\delta}$. This minor phase segregation was also reported by Avci and Huq in the $\mathrm{YBaCo}_{4} \mathrm{O}_{7+\delta}$ system and such a phase could be eliminated by synthesizing in a reducing atmosphere $[35,36]$. The Rietveld refinement plots and detailed structural solutions for all three compounds are summarized in Fig. 2 and Table 1.

Interestingly, $\mathrm{Zn}$ ions were found to have higher preference to stay at the $6 c$ sites than at the $2 a$ sites in $\mathrm{YBaCo}_{3} \mathrm{ZnO}_{7+\delta}$. The same behavior was also observed in $\mathrm{Y}_{0.9} \mathrm{In}_{0.1} \mathrm{BaCo}_{3} \mathrm{ZnO}_{7+\delta}$ and $\mathrm{Y}_{0.9} \mathrm{In}_{0.1} \mathrm{BaCo}_{3} \mathrm{Zn}_{0.6} \mathrm{Fe}_{0.4} \mathrm{O}_{7+\delta}$. However, more Fe ions were found at the $2 a$ sites than at the $6 c$ sites. Consequently, the Co ions at the $6 c$ sites have longer Co-O bond length $(1.910 \AA \mathrm{x} 1$; $1.921 \AA \mathrm{x} 1 ; 1.930 \AA \mathrm{x} 1 ; 1.981 \AA \mathrm{x} 1)$ than that at the $2 a$ sites $(1.892 \AA \mathrm{x} 3 ; 1.907 \AA \mathrm{x} 1)$. The bond valence sum calculation (Table 2) revealed that a lower valence was found for Co ions at the $6 c$ sites $\left(\mathrm{Co}^{2.08+}\right)$ than at the $2 a$ sites $\left(\mathrm{Co}^{2.18+}\right)$ sites.

Selected area electron microscopy (SAED) data were also collected for $\mathrm{YBaCo}_{3} \mathrm{ZnO}_{7+\delta}$, $\mathrm{Y}_{0.9} \mathrm{In}_{0.1} \mathrm{Co}_{3} \mathrm{ZnO}_{7+\delta}$ and $\mathrm{Y}_{0.9} \mathrm{In}_{0.1} \mathrm{Co}_{3} \mathrm{Zn}_{0.6} \mathrm{Fe}_{0.4} \mathrm{O}_{7+\delta}$ to confirm the crystal structure at the grain level. As shown in Fig. 1e-f, all the SAED images can also be indexed with the P31c structure. 
The cell parameters of the compounds are in good agreement with the values obtained with the Rietveld refinement analysis.

\subsection{Bulk and anisotropic thermal expansion coefficients of cation-substituted $\mathrm{YBaCo}_{4} \mathrm{O}_{7}$}

To evaluate the structural stability of $\mathrm{YBaCo}_{3} \mathrm{ZnO}_{7+\delta}, \quad \mathrm{Y}_{0.9} \mathrm{In}_{0.1} \mathrm{Co}_{3} \mathrm{ZnO}_{7+\delta}$, and $\mathrm{Y}_{0.9} \mathrm{In}_{0.1} \mathrm{Co}_{3} \mathrm{Zn}_{0.6} \mathrm{Fe}_{0.4} \mathrm{O}_{7+\delta}$, in-situ time-of-flight (TOF) neutron diffraction data were collected between 25 and $800{ }^{\circ} \mathrm{C}$ in air. The compounds were stable without decomposition in the whole temperature range and the patterns could be indexed with the $P 31 c$ structure. This provides an important criterion to further study the anisotropic TECs from the change in cell parameters at different temperatures. The cell parameters were obtained from the Rietveld refinement of the neutron diffraction. As shown in Fig. 3, both the cell parameters $a$ and $c$ increase with increasing temperature. However, over the whole temperature range, the slope of $c$ was larger than that of $a$, indicating that the anisotropic TECs along the $x$-axis were smaller than that along the $z$-axis for all the samples. This interesting result indicates that the low bulk TEC of the cation-substituted $\mathrm{YBaCo}_{4} \mathrm{O}_{7+\delta}$ compounds was mainly due to the low anisotropic thermal expansion coefficient along the $x$-axis (Fig. 4).

One can design a low TEC material by suppressing both the anisotropic TECs along the $x$ and $z$-axes. Nonetheless, our experimental results showed that this desired goal cannot be achieved by using a single dopant (e.g., Zn or In). Although the use of a small amount of In to substitute for $\mathrm{Y}$ was helpful to improve the phase stability at elevated temperatures, the anisotropic TEC along the $x$-axis of $\mathrm{Y}_{0.9} \mathrm{In}_{0.1} \mathrm{BaCo}_{3} \mathrm{ZnO}_{7+\delta}$ was larger than that of $\mathrm{YBaCo}_{3} \mathrm{ZnO}_{7+\delta}$. Surprisingly, the codoping of In for $\mathrm{Y}$, and $\mathrm{Fe}$ and $\mathrm{Zn}$ for $\mathrm{Co}$ in $\mathrm{YBaCo}_{4} \mathrm{O}_{7+\delta}$ was necessary to tailor the phase stability and suppress both the anisotropic TEC values. The lowest bulk TEC was 
$9.06 \times 10^{-6}{ }^{\circ} \mathrm{C}^{-1}$ for $\mathrm{Y}_{0.9} \mathrm{In}_{0.1} \mathrm{Co}_{3} \mathrm{Zn}_{0.6} \mathrm{Fe}_{0.4} \mathrm{O}_{7+\delta}$, with the anisotropic TECs along $x$ - and $z$-axes of 8.94 and $9.19 \times 10^{-6}{ }^{\circ} \mathrm{C}^{-1}$, respectively (Table 3).

For many Co-based perovskite-type cathodes, the large TEC of the unit cell parameters is triggered by three main factors: low-spin to high-spin transition of $\mathrm{Co}^{3+}$ ions, reduction of $\mathrm{Co}^{3+/ 4+}$ ions, and the formation of oxide-ion vacancies $[19,39]$. As all of the Co ions are located in the tetrahedral sites in the cation-substituted $\mathrm{YBaCo}_{4} \mathrm{O}_{7+\delta}$ compounds, so the spin-state transition is eliminated. The second and third factors were investigated by Rietveld refinement of in-situ neutron diffraction data, thermogravimetric analysis, and bond valence sum map.

The oxide-ion occupancies (in $\mathrm{O} 1, \mathrm{O} 2$ and $\mathrm{O} 3$ sites) were refined as a function of temperature. The occupancies were found to be very close to 1 and they were unchanged with temperature, suggesting that oxide-ion vacancy was not created at elevated temperatures. The weight change of the samples was studied as a function of temperature in TGA (Fig. 5). In the low-temperature range $\left(100-250{ }^{\circ} \mathrm{C}\right)$, an increase in weight was observed due to the oxygen absorption behavior [40, 41]. However, such oxygen undergoes sharp desorption as the temperature increases to $>250{ }^{\circ} \mathrm{C}$. In the high-temperature range, only a small weight loss was found for all compounds, implying that the reduction of Co ions is insignificant at high temperatures.

As the in-situ neutron diffraction ruled out the possibility of oxide-ion vacancy formation at elevated temperatures, the weight loss in the high-temperature range could be due to oxygen loss from interstitial sites. This mechanism was supported by the low valence unit (v.u.; ca. 0.05) mismatch for oxygen atoms which were found around the $\mathrm{YO}_{6}, \mathrm{BaO}_{12}$, and $\mathrm{CoO}_{4}$ polyhedra (Fig. $6)$. 
In general, the TEC describes how a compound changes unit cell parameter in response to temperature. Such a change can be reflected by the change of the size of the $\mathrm{MO}_{\mathrm{n}}(\mathrm{M}=\mathrm{Y}, \mathrm{Ba}$, Co; $\mathrm{n}=4$ - 12) polyhedra in the $\mathrm{YBaCo}_{4} \mathrm{O}_{7+\delta}$-type compounds, which was studied indirectly from the change of M-O bond lengths. Particularly, the change in the bond length of $\mathrm{Co}-\mathrm{O}(2 \%<)$ in $\mathrm{CO}_{4}$ tetrahedra is crucial as the valence of Co changes with temperature, while the changes in $\mathrm{Ba}-\mathrm{O}(0.7 \%<)$ and $\mathrm{Y}-\mathrm{O}(0.2 \%<)$ bond lengths were found to be $3-10$ times smaller than that for the former. Since the Co atoms are located in the $2 a$ and $6 c$ sites, their bond lengths were compared separately. Interestingly, the change in Co-O bond lengths were larger for Co atoms located in the $2 a$ site than that in the the $6 c$ sites for all compounds. The substitution of In for Y ions could suppress the change in Co-O length for $\mathrm{Co}$ at the $2 a$ site in $\mathrm{Y}_{0.9} \mathrm{In}_{0.1} \mathrm{BaCo}_{3} \mathrm{ZnO}_{7}$. Additionally, the co-substitution of In for $\mathrm{Y}$, and $\mathrm{Zn}$ and Fe for Co can further reduce the change in Co-O lengths for Co ions at the $2 a$ and $6 c$ sites in $\mathrm{Y}_{0.9} \mathrm{In}_{0.1} \mathrm{BaCo}_{3} \mathrm{Zn}_{0.6} \mathrm{Fe}_{0.4} \mathrm{O}_{7+\delta}$ (Fig. 7), resulting in its lowest bulk TEC among the investigated compounds.

\subsection{Impact of dopants on the polarization resistance of cation-substituted $\mathrm{YBaCo}_{4} \mathrm{O}_{7+\delta}$}

The catalytic activity of the cation-substituted $\mathrm{YBaCo}_{4} \mathrm{O}_{7+\delta}$ compounds was studied by electrochemical impedance spectroscopy with a symmetrical-cell configuration between 500 and $700{ }^{\circ} \mathrm{C}$. The high-frequency intercepts were interpreted as the ohmic losses $\left(\mathrm{R}_{\mathrm{s}}\right)$ and the polarization resistances $\left(\mathrm{R}_{\mathrm{p}}\right)$ occur in the intermediate to low frequency. For all samples, the polarization resistances of the symmetrical cells were found to decrease with increasing temperature (Fig. 8 and Table 4). The cathodic polarization resistance used in Fig. $8 \mathrm{~b}$ is the half value of the resistance $\left(\mathrm{R}_{\text {total }} / 2\right)$ of a symmetrical cell shown in Fig. $8 \mathrm{a}$. 
At the low-temperature regime (ca. $500{ }^{\circ} \mathrm{C}$ ), the impedance spectra can be fitted with 4 equivalent circuits R-CPE, where R (R1 - R4) and CPE (CPE1 - CPE4) are the resistance and constant phase element, respectively. Based on their capacitances, the polarization resistances can be interpreted as losses from the electrochemical processes at the anode $\left(R_{\text {ano }}\right)$ and cathode $\left(\mathrm{R}_{\text {cat }}\right)$ and losses from concentration and gas conversion at the anode $\left(\mathrm{R}_{\text {Conc,ano }}\right)$ and cathode $\left(\mathrm{R}_{\text {Conc,cat }}\right)[42,43]$. At the high-temperature regime (ca. $700{ }^{\circ} \mathrm{C}$ ), the first two semi-circles disappears as the electrochemical processes are thermally activated. Among the investigated compounds, the lowest area-specific resistance of cathodic polarization was found to be 0.14 ohm $\mathrm{cm}^{2}\left(\mathrm{R}_{\text {total }} / 2\right)$ for $\mathrm{Y}_{0.9} \mathrm{In}_{0.1} \mathrm{BaCo}_{3} \mathrm{Zn}_{0.6} \mathrm{Fe}_{0.4} \mathrm{O}_{7+\delta}$ at $700{ }^{\circ} \mathrm{C}$. The Arrhenius plot of the $\mathrm{R}_{\mathrm{p}}$ values is shown in Fig. 8b. All the samples have a comparable activation energy $\left(\mathrm{E}_{\mathrm{a}}\right)$ of ca. $1.2 \mathrm{eV}$, indicating that the electrochemical processes are similar. The lowest $\mathrm{E}_{\mathrm{a}}$ was found to be $1.18 \mathrm{eV}$ for $\mathrm{Y}_{0.9} \mathrm{In}_{0.1} \mathrm{BaCo}_{3} \mathrm{ZnO}_{7+\delta}$.

\section{Conclusions}

$\mathrm{YBaCo}_{3} \mathrm{ZnO}_{7+\delta}, \mathrm{Y}_{0.9} \mathrm{In}_{0.1} \mathrm{BaCo}_{3} \mathrm{ZnO}_{7+\delta}$, and $\mathrm{Y}_{0.9} \mathrm{In}_{0.1} \mathrm{BaCo}_{3} \mathrm{Zn}_{0.6} \mathrm{Fe}_{0.4} \mathrm{O}_{7+\delta}$ have been studied by in-situ time of flight (TOF) neutron diffraction, bond valence sum map, thermogravimetic analysis, and dilatometry to reveal the low thermal expansion coefficients. The bulk TEC of $\mathrm{YBaCo}_{3} \mathrm{ZnO}_{7+\delta}, \mathrm{Y}_{0.9} \mathrm{In}_{0.1} \mathrm{BaCo}_{3} \mathrm{ZnO}_{7+\delta}$, and $\mathrm{Y}_{0.9} \mathrm{In}_{0.1} \mathrm{BaCo}_{3} \mathrm{Zn}_{0.6} \mathrm{Fe}_{0.4} \mathrm{O}_{7+\delta}$ is in the range of 9.06 and $9.76 \times 10^{-6}{ }^{\circ} \mathrm{C}^{-1}$. With the use of In for $\mathrm{Y}$ and $\mathrm{Zn}$ and $\mathrm{Fe}$ for $\mathrm{Co}$ as co-dopants, the anisotropic (along $x$-axis) and bulk TECs could be reduced to 8.94 and $9.06 \times 10^{-6}{ }^{\circ} \mathrm{C}^{-1}$, respectively. The reduction is due to the suppression of the change in the $\mathrm{Co}-\mathrm{O}$ bond length in $\mathrm{CoO}_{4}$ polyhedra. Bond valence sum map reveals that the weight loss is due to the loss of interstitial oxide ions. $\mathrm{Y}_{0.9} \mathrm{In}_{0.1} \mathrm{BaCo}_{3} \mathrm{Zn}_{0.6} \mathrm{Fe}_{0.4} \mathrm{O}_{7}$ has the lowest area-specific cathodic polarization resistance of ca. $0.14 \mathrm{ohm} \mathrm{cm}{ }^{2}\left(\mathrm{R}_{\text {total }} / 2\right)$ at $700{ }^{\circ} \mathrm{C}$. 


\section{Acknowledgements}

The work was supported by the Welch Foundation Grant F-1254. The in-situ neutron diffraction measurement at the Powgen beamline at the Oak Ridge National Laboratory's (ORNL) Spallation Neutron Source (SNS) was sponsored by the Scientific User Facilities Division, Office of Basic Energy Sciences, US Department of Energy. The authors appreciate the assistance from Drs. Melanie Kirkham and Pamela Whitfield at the POWGEN Instrument Team, SNS, ORNL, and Dr. Yubao Zhao for measuring the electron diffraction of our samples. Use of the Advanced Photon Source at Argonne National Laboratory was supported by the U. S. Department of Energy, Office of Science, Office of Basic Energy Sciences, under Contract No. DE-AC02-06CH11357.

\section{References}

[1] W.H. Kan, V. Thangadurai, Ionics, 21 (2015) 301.

[2] A. Atkinson, S. Barnett, R.J. Gorte, J.T.S. Irvine, A.J. McEvoy, M. Mogensen, S.C.

Singhal, J. Vohs, Nat. Mater., 3 (2004) 17.

[3] Redoxenergy, in, Redox Power System, LLC.

[4] Bloomenergy, in.

[5] S.C. Singhal, Solid State Ionics, 135 (2000) 305.

[6] A. Petric, P. Huang, F. Tietz, Solid State Ionics, 135 (2000) 719.

[7] S. McIntosh, J.F. Vente, W.G. Haije, D.H.A. Blank, H.J.M. Bouwmeester, Chem. Mater., 18 (2006) 2187.

[8] S. Hui, A. Petric, J. Eur. Cera. Soc., 22 (2002) 1673. 
[9] Y. Du, N.M. Sammes, G.A. Tompsett, D. Zhang, J. Swan, M. Bowden, J. Electrochem. Soc., 150 (2003) A74.

[10] K. Park, S. Yu, J. Bae, H. Kim, Y. Ko, Int. J. Hydrogen Energy, 35 (2010) 8670.

[11] E.V. Tsipis, V.V. Kharton, J.R. Frade, Solid State Ionics, 177 (2006) 1823.

[12] W.H. Kan, J. Lussier, M. Bieringer, V. Thangadurai, Inorg. Chem., 53 (2014) 10085.

[13] W.H. Kan, M. Roushanafshar, A. Vincent, T. Fürstenhaupt, M. Parvez, J. Luo, V. Thangadurai, RSC Adv., 3 (2013) 23824.

[14] M. Valldor, Solid State Sciences, 6 (2004) 251.

[15] M. West, S.-J. Sher, A. Manthiram, J. Power Sources, 271 (2014) 252.

[16] M. West, A. Manthiram, Int. J. Hydrogen Energy, 39 (2014) 19722.

[17] V.B. Vert, J.M. Serra, J.L. Jordá, Electrochem. Commun., 12 (2010) 278.

[18] J.-H. Kim, Y.N. Kim, S.M. Cho, H. Wang, A. Manthiram, Electrochim. Acta, 55 (2010) 5312.

[19] J.-H. Kim, A. Manthiram, Chem. Mater., 22 (2010) 822.

[20] Y.N. Kim, J.H. Kim, A. Huq, M.P. Paranthaman, A. Manthiram, J. Power Sources, 214 (2012) 7.

[21] Y.N. Kim, J.-H. Kim, A. Manthiram, Int. J. Hydrogen Energy, 36 (2011) 15295.

[22] O. Parkkima, M. Karppinen, Eur. J. Inorg. Chem. , 2014 (2014) 4056.

[23] A. Kleiman-Shwarsctein, M.N. Huda, A. Walsh, Y. Yan, G.D. Stucky, Y.-S. Hu, M.M. Al-Jassim, E.W. McFarland, Chem. Mater., 22 (2010) 510.

[24] F. Wang, C. Di Valentin, G. Pacchioni, J. Phys. Chem. C, 116 (2012) 8901.

[25] C.A.J. Fisher, B. Derby, R.J. Brook, Br. Ceram. Proc., 56 (1996) 25.

[26] P. Zhang, Y. Zhao, X. Wang, Dalton Trans., 44 (2015) 10932. 
[27] B.H. Toby, J. Appl. Cryst., 34 (2001) 210.

[28] I.D. Brown, J. Appl. Cryst., 29 (1996) 479.

[29] A.S. Wills, in, Program available from www.ccp14.ac.uk, pp. Program available from www.ccp14.ac.uk.

[30] M. Sale, M. Avdeev, J. Appl. Cryst., 45 (2012) 1054.

[31] ZView - Scribner Associates Inc.

[32] M. Valldor, M. Andersson, Solid State Sciences, 4 (2002) 923.

[33] C. Rabbow, H. Müller-Buschbaum, Z. Naturforsch., 51 (1996) 343.

[34] C. Rabbow, S. Panzer, H.M. üller-Buschbaum, Z. Naturforsch., 52 (1997) 546.

[35] S. Avci, O. Chmaissem, H. Zheng, A. Huq, P. Manuel, J.F. Mitchell, Chem. Mater., 25 (2013) 4188-4196.

[36] A. Huq, J.F. Mitchell, H. Zheng, L.C. Chapon, P.G. Radaelli, K.S. Knight, P.W.

Stephens, J. Solid State Chem., 179 (2006) 1136.

[37] D.T. Cromer, J.T. Waber, Atomic scattering factors for x-rays, in: J.A. Ibers, W.C. Hamilton (Eds.) Int. Tables X-Ray Crystallogr., 1974, pp. 71.

[38] V.F. Sears, Neutron News, 3 (1992) 29.

[39] L.-W. Tai, M.M. Nasrallah, H.U. Anderson, D.M. Sparlin, S.R. Sehlin, Solid State Ionics, 76 (1995) 273.

[40] O. Parkkima, H. Yamauchi, M. Karppinen, Chem. Mater., 25 (2013) 599.

[41] Y. Jia, H. Jiang, M. Valkeapa, H. Yamauchi, M. Karppinen, E.I. Kauppinen, J. Am.

Chem. Soc., 131 (2009) 4880.

[42] J.T.S. Irvine, D.C. Sinclair, A.R. West, Adv. Mater. , 2 (1990) 132. 
[43] W.H. Kan, M. Chen, J.-S. Bae, B.-H. Kim, V. Thangadurai, J. Mater. Chem. A, 2 (2014) 8736.

[44] A. Mai, V.A.C. Haanappel, S. Uhlenbruck, F. Tietz, D. Sto“ver, Solid State Ionics, 176 (2005) 1341. 


\section{Table}

Table 1 Structural solution of joint synchrotron $\mathrm{X}$-ray and time of flight neutron Rietveld refinement of $\mathrm{YBaCo}_{3} \mathrm{ZnO}_{7+\delta}, \mathrm{Y}_{0.9} \mathrm{In}_{0.1} \mathrm{BaCo}_{3} \mathrm{ZnO}_{7+\delta}$, and $\mathrm{Y}_{0.9} \mathrm{In}_{0.1} \mathrm{BaCo}_{3} \mathrm{Zn}_{0.6} \mathrm{Fe}_{0.4} \mathrm{O}_{7+\delta}$ at $25{ }^{\circ} \mathrm{C}$.

\begin{tabular}{|c|c|c|c|c|}
\hline \multicolumn{5}{|c|}{$\begin{array}{c}\mathrm{YBaCo}_{3} \mathrm{ZnO}_{7+\delta} \\
\mathrm{Rwp}=7.99 \% ; P 31 c(159) ; a=6.306202(7) \AA ; c=10.26393(1) \AA ; \mathrm{V}=353.492(1) \AA^{3}\end{array}$} \\
\hline Atom & Wycf. position & $x / a, y / b, c / z$ & Fraction & $100 *$ Uiso \\
\hline $\mathrm{O} 1$ & $6 c$ & $0.3264(5), 0.175(2), 0.0596(3)$ & 1 & $\mathrm{a}$ \\
\hline $\mathrm{Co} 2$ & $6 c$ & $0.34149(9), 0.1749(3), 0.2474(1)$ & $0.692(8)$ & $0.53(2)$ \\
\hline $\mathrm{Zn} 2$ & $6 c$ & $0.34149(9), 0.1749(3), 0.2474(1)$ & $0.308(8)$ & $0.53(2)$ \\
\hline $\mathrm{O} 2$ & $6 c$ & $0.0041(7), 0.497(2), 0.3083(3)$ & 1 & $\mathrm{~b}$ \\
\hline Y & $2 a$ & $0.3333,0.6667,0.43530(6)$ & 1 & $0.56(3)$ \\
\hline $\mathrm{Ba}$ & $2 a$ & $0.3333,0.6667,0.061551$ & 1 & $1.65(3)$ \\
\hline Co1 & $2 a$ & $0,0,-0.0018(3)$ & $0.78(1)$ & $0.46(2)$ \\
\hline $\mathrm{Zn} 1$ & $2 a$ & $0,0,-0.0018(3)$ & $0.22(1)$ & $0.46(2)$ \\
\hline $\mathrm{O} 3$ & $2 a$ & $0,0,0.3124(4)$ & 1 & \\
\hline
\end{tabular}

\begin{tabular}{|c|c|c|c|c|}
\hline \multicolumn{5}{|c|}{$\begin{array}{c}\mathbf{Y}_{0.9} \mathbf{I n}_{0.1} \mathrm{BaC0}_{3} \mathrm{ZnO}_{7+\delta} \\
\mathrm{Rwp}=7.97 \% ; P 31 c(159) ; a=6.298325(5) \AA ; c=10.26234(1) \AA ; \mathrm{V}=352.555(1) \AA^{3}\end{array}$} \\
\hline Atom & Wycf.position & $x / a, y / b, c / z$ & Fraction & $100 *$ Uiso \\
\hline $\mathrm{O} 1$ & $6 c$ & $0.3278(4), 0.1984(4), 0.0588(3)$ & 1 & $\mathrm{a}$ \\
\hline $\mathrm{Co} 2$ & $6 c$ & $0.34160(7), 0.1747(2), 0.2472(1)$ & $0.683(3)$ & $0.533(9)$ \\
\hline $\mathrm{Zn} 2$ & $6 c$ & $0.34160(7), 0.1747(2), 0.2472(1)$ & $0.317(3)$ & $0.533(9)$ \\
\hline $\mathrm{O} 2$ & $6 c$ & $0.0028(6), 0.4916(6), 0.3104(3)$ & 1 & $\mathrm{~b}$ \\
\hline $\mathrm{Y}$ & $2 a$ & $0.3333,0.6667,0.43628(5)$ & 0.9 & $0.49(2)$ \\
\hline In & $2 a$ & $0.3333,0.6667,0.43628(5)$ & 0.1 & $0.49(2)$ \\
\hline $\mathrm{Ba}$ & $2 a$ & $0.3333,0.6667,0.061551$ & 1 & $1.43(2)$ \\
\hline Co1 & $2 a$ & $0,0,-0.0017(2)$ & $0.812(9)$ & $0.33(2)$ \\
\hline $\mathrm{Zn} 1$ & $2 a$ & $0,0,-0.0017(2)$ & $0.188(9)$ & $0.33(2)$ \\
\hline $\mathrm{O} 3$ & $2 a$ & $0,0,0.3100(3)$ & 1 & $\mathrm{c}^{\mathrm{c}}$ \\
\hline
\end{tabular}

\begin{tabular}{|c|c|c|c|c|}
\hline \multicolumn{5}{|c|}{$\begin{array}{c}\mathbf{Y}_{0.9} \mathbf{I n}_{0.1} \mathbf{B a C o}_{3} \mathbf{Z n}_{0.6} \mathbf{F e}_{0.4} \mathbf{O}_{7+\delta} \\
\operatorname{Rwp}=6.3 \% ; P 31 c(159) ; a=6.303287(4) \AA ; c=10.260676(8) \AA ; \mathrm{V}=353.054(1) \AA^{3}\end{array}$} \\
\hline Atom & Wycf.position & $x / a, y / b, c / z$ & Fraction & $100 *$ Uiso \\
\hline $\mathrm{O} 1$ & $6 c$ & $0.3273(3), 0.167(2), 0.0573(3)$ & 1 & $\mathrm{a}$ \\
\hline $\mathrm{Co} 2$ & $6 c$ & $0.34232(6), 0.1667(5), 0.2471(1)$ & $0.756(4)$ & $0.652(8)$ \\
\hline $\mathrm{Zn} 2$ & $6 c$ & $0.34232(6), 0.1667(5), 0.2471(1)$ & $0.160(4)$ & $0.652(8)$ \\
\hline $\mathrm{Fe} 2$ & $6 c$ & $0.34232(6), 0.1667(5), 0.2471(1)$ & $0.084(4)$ & $0.652(8)$ \\
\hline $\mathrm{O} 2$ & $6 c$ & $0.0067(6), 0.4883(8), 0.3076(2)$ & 1 & $\mathrm{~b}$ \\
\hline $\mathrm{Y}$ & $2 a$ & $0.3333,0.6667,0.43506(4)$ & 0.9 & $0.83(2)$ \\
\hline In & $2 a$ & $0.3333,0.6667,0.43506(4)$ & 0.1 & $0.83(2)$ \\
\hline $\mathrm{Ba}$ & $2 a$ & $0.3333,0.6667,0.061551$ & 1 & $1.43(2)$ \\
\hline $\mathrm{Co} 1$ & $2 a$ & $0,0,-0.0013(2)$ & $0.732(8)$ & $0.57(2)$ \\
\hline $\mathrm{Zn} 1$ & $2 a$ & $0,0,-0.0013(2)$ & $0.121(8)$ & $0.57(2)$ \\
\hline Fe1 & $2 a$ & $0,0,-0.0013(2)$ & $0.147(8)$ & $0.57(2)$ \\
\hline $\mathrm{O} 3$ & $2 a$ & $0,0,0.3095(3)$ & 1 & \\
\hline
\end{tabular}


Table 2 Bond length and bond valence sum (BVS) analysis of $\mathrm{YBaCo}_{3} \mathrm{ZnO}_{7+\delta}$, $\mathrm{Y}_{0.9} \mathrm{In}_{0.1} \mathrm{BaCo}_{3} \mathrm{ZnO}_{7+\delta}$, and $\mathrm{Y}_{0.9} \mathrm{In}_{0.1} \mathrm{BaCo}_{3} \mathrm{Fe}_{0.6} \mathrm{Zn}_{0.4} \mathrm{O}_{7+\delta}$ at $25{ }^{\circ} \mathrm{C}$.

\begin{tabular}{|c|c|c|}
\hline \multicolumn{3}{|c|}{$\mathrm{YBaCo}_{3} \mathrm{ZnO}_{7+\delta}$} \\
\hline Bond & Bond length $(\AA) \times$ time & $\begin{array}{l}\text { Average Bond valence } \\
\text { Sum }\end{array}$ \\
\hline $\mathrm{Y}-\mathrm{O}$ & $2.221 \times 3 ; 2.256 \times 3$ & 3.32 \\
\hline $\mathrm{Ba}-\mathrm{O}$ & $\begin{array}{l}3.079 \times 3 ; 3.106 \times 3 \\
3.187 \times 3 ; 3.228 \times 3\end{array}$ & 1.17 \\
\hline $\mathrm{Co}(2)-\mathrm{O}$ & $1.910 \times 1 ; 1.921 \times 1$ & 2.08 \\
\hline $\mathrm{Zn}(2)-\mathrm{O}$ & $1.930 \times 1 ; 1.981 \times 1$ & 2.26 \\
\hline $\mathrm{Co}(1)-\mathrm{O}$ & $1.892 \times 3 ; 1.907 \times 1$ & 2.18 \\
\hline $\mathrm{Zn}(1)-\mathrm{O}$ & & 2.15 \\
\hline \multicolumn{3}{|c|}{$\mathrm{Y}_{0.9} \mathrm{In}_{0.1} \mathrm{BaCo}_{3} \mathrm{ZnO}_{7+\delta}$} \\
\hline $\mathrm{Y}-\mathrm{O}$ & 2.189 x $3 ; 2.246$ x 3 & 3.34 \\
\hline In-O & & 2.42 \\
\hline $\mathrm{Ba}-\mathrm{O}$ & $\begin{array}{l}2.932 \times 3 ; 3.126 \times 3 ; \\
3.164 \times 3 ; 3.367 \times 3\end{array}$ & 1.26 \\
\hline $\mathrm{Co}(2)-\mathrm{O}$ & $1.905 \times 3 ; 1.932 \times 1$ & 2.18 \\
\hline $\mathrm{Zn}(2)-\mathrm{O}$ & & 2.25 \\
\hline $\mathrm{Co}(1)-\mathrm{O}$ & $1.888 \times 1 ; 1.972 \times 3$ & 2.05 \\
\hline $\mathrm{Zn}(1)-\mathrm{O}$ & & 2.12 \\
\hline \multicolumn{3}{|c|}{$\mathrm{Y}_{0.9} \mathrm{In}_{0.1} \mathrm{BaCo}_{3} \mathrm{Fe}_{0.6} \mathrm{Zn}_{0.4} \mathrm{O}_{7+\delta}$} \\
\hline $\mathrm{Y}-\mathrm{O}$ & $2.134 \times 3 ; 2.237$ × 3 & 3.44 \\
\hline In-O & & 2.50 \\
\hline $\mathrm{Ba}-\mathrm{O}$ & $\begin{array}{l}3.093 \times 3 ; 3.131 \times 3 ; \\
3.173 \times 3 ; 3.200 \times 3\end{array}$ & 1.17 \\
\hline $\mathrm{Co}(2)-\mathrm{O}$ & & 2.28 \\
\hline $\mathrm{Fe}(2)-\mathrm{O}$ & $1.885 \times 3 ; 1.942 \times 1$ & 2.73 \\
\hline $\mathrm{Zn}(2)-\mathrm{O}$ & & 2.35 \\
\hline $\mathrm{Co}(1)-\mathrm{O}$ & $1.820 \times 1 ; 1.950 \times 1 ;$ & 2.07 \\
\hline $\mathrm{Fe}(1)-\mathrm{O}$ & $1.975 \times 1 ; 2.018 \times 1$ & 2.32 \\
\hline $\mathrm{Zn}(1)-\mathrm{O}$ & & 2.14 \\
\hline
\end{tabular}


Table 3 Comparison of the anisotropic and isotropic thermal expansion coefficient $\left(10^{-6}{ }^{\circ} \mathrm{C}^{-1}\right)$ of $\mathrm{YBaCo}_{3} \mathrm{ZnO}_{7+\delta}, \mathrm{Y}_{0.9} \mathrm{In}_{0.1} \mathrm{BaCo}_{3} \mathrm{ZnO}_{7+\delta}$, and $\mathrm{Y}_{0.9} \mathrm{In}_{0.1} \mathrm{BaCo}_{3} \mathrm{Zn}_{0.6} \mathrm{Fe}_{0.4} \mathrm{O}_{7+\delta}$ between 25 and $800{ }^{\circ} \mathrm{C}$.

\begin{tabular}{ccccc}
\hline Sample & along $\boldsymbol{x}$-axis & along -axis & isotropic $\left(\mathbf{7 0 0}^{\mathbf{0}} \mathbf{C}\right)$ & Reference \\
\hline $\mathrm{YBaCo}_{3} \mathrm{ZnO}_{7+\delta}$ & 8.93 & 9.84 & 9.42 & This work \\
$\mathrm{Y}_{0.9} \mathrm{In}_{0.1} \mathrm{BaCo}_{3} \mathrm{ZnO}_{7+\delta}$ & 9.13 & 9.24 & 9.76 & This work \\
$\mathrm{Y}_{0.9} \mathrm{In}_{0.1} \mathrm{BaCo}_{3} \mathrm{Zn}_{0.6} \mathrm{Fe}_{0.4} \mathrm{O}_{7+\delta}$ & 8.94 & 9.19 & 9.06 & This work \\
$\mathrm{La}_{0.65} \mathrm{Sr}_{0.3} \mathrm{MnO}_{3-\delta}$ & - & - & 12.3 & {$[44]$} \\
$\mathrm{La}_{0.6} \mathrm{Sr}_{0.4} \mathrm{CoO}_{3-\delta}$ & - & - & 20.5 & {$[6]$} \\
$\mathrm{La}_{0.3} \mathrm{Sr}_{0.7} \mathrm{Co}_{0.9} \mathrm{Fe}_{0.1} \mathrm{O}_{3-\delta}$ & - & - & 19.3 & {$[6]$} \\
$\mathrm{Ba}_{0.5} \mathrm{Sr}_{0.5} \mathrm{Co}_{0.8} \mathrm{Fe}_{0.2} \mathrm{O}_{3-\delta}$ & - & - & 20.8 & {$[7]$} \\
$\mathrm{La}_{0.8} \mathrm{Sr}_{0.2} \mathrm{Ga}_{0.8} \mathrm{Mg}_{0.2} \mathrm{O}_{3-\delta}$ & - & - & 11.3 & {$[8]$} \\
$\mathrm{Gd}_{0.1} \mathrm{Ce}_{0.9} \mathrm{O}_{1.95}$ & - & - & 12.0 & {$[9]$} \\
$\mathrm{Y}_{0.16} \mathrm{Zr}_{0.84} \mathrm{O}_{1.92}$ & - & - & 10.8 & {$[8]$} \\
\hline
\end{tabular}


Table 4 Effect of temperature on the EIS elements of a two-electrode symmetrical cell study

\begin{tabular}{|c|c|c|c|c|c|c|c|c|c|c|c|c|c|c|}
\hline Cathode & Temperature & $\begin{array}{c}\mathbf{R}_{\mathrm{s}} \\
\left(\mathbf{\Omega c m}^{2}\right)\end{array}$ & $\begin{array}{c}\mathbf{R}_{1} \\
\left(\Omega \mathrm{cm}^{2}\right)\end{array}$ & $\begin{array}{c}\mathrm{CPE}_{1} \\
\left(\mathrm{Fcm}^{-2}\right)\end{array}$ & $\mathbf{n}_{1}$ & $\begin{array}{c}\mathbf{R}_{2} \\
\left(\Omega \mathrm{cm}^{2}\right)\end{array}$ & $\begin{array}{c}\mathrm{CPE}_{2} \\
\left(\mathrm{Fcm}^{-2}\right)\end{array}$ & $\mathbf{n}_{2}$ & $\begin{array}{c}\mathbf{R}_{\mathbf{3}} \\
\left(\boldsymbol{\Omega} \mathrm{cm}^{2}\right)\end{array}$ & $\begin{array}{c}\mathrm{CPE}_{3} \\
\left(\mathrm{Fcm}^{-2}\right)\end{array}$ & $\mathbf{n}_{3}$ & $\begin{array}{c}\mathbf{R}_{\mathbf{4}} \\
\left(\Omega \mathrm{cm}^{2}\right)\end{array}$ & $\begin{array}{c}\mathrm{CPE}_{4} \\
\left(\mathrm{Fcm}^{-2}\right)\end{array}$ & $\begin{array}{ll}\mathbf{n}_{4} \chi^{2} \\
\end{array}$ \\
\hline $\mathrm{YBaCo}_{3} \mathrm{ZnO}_{7+\delta}$ & $500{ }^{\circ} \mathrm{C}$ & 9.14 & 4.28 & $\begin{array}{c}3.48 \\
\text { E-6 }\end{array}$ & 0.9 & 4.5 & $\begin{array}{l}3.3 \\
\text { E-6 }\end{array}$ & 0.9 & 2.1 & $1 \mathrm{E}-2$ & 0.64 & 2.3 & $4 \mathrm{E}-2$ & $\begin{array}{r}0.837 .2 \\
\text { E-3 }\end{array}$ \\
\hline $\mathrm{BaCO}_{3} \mathrm{ZnO}_{7+\delta}$ & $550{ }^{\circ} \mathrm{C}$ & 5.35 & 0.53 & $\begin{array}{l}4.39 \\
\text { E-6 }\end{array}$ & 0.99 & 2.38 & $\begin{array}{l}3.3 \\
\text { E-6 }\end{array}$ & 0.9 & 0.89 & $3 \mathrm{E}-3$ & 0.8 & 1.32 & $2 \mathrm{E}-2$ & $\begin{array}{r}0.839 .0 \\
\text { E-3 }\end{array}$ \\
\hline $\mathrm{YBaCo}_{3} \mathrm{ZnO}_{7+\delta}$ & $600{ }^{\circ} \mathrm{C}$ & 3.83 & 0.58 & $\begin{array}{l}3.75 \\
\text { E-4 }\end{array}$ & 0.64 & 0.14 & $\begin{array}{l}1.15 \\
\text { E-3 }\end{array}$ & 0.9 & 0.6 & $2 \mathrm{E}-3$ & 0.9 & 0.36 & $3 \mathrm{E}-2$ & $\begin{array}{r}0.93 .5 \\
\text { E-3 }\end{array}$ \\
\hline $\mathrm{YBaCO}_{3} \mathrm{ZnO}_{7+\delta}$ & $650{ }^{\circ} \mathrm{C}$ & 2.56 & 0.3 & $\begin{array}{l}1.19 \\
\text { E-3 }\end{array}$ & 0.85 & 0.33 & $\begin{array}{l}2.27 \\
\text { E-2 }\end{array}$ & 0.67 & & & & & & $\begin{array}{l}7.8 \\
\text { E-4 }\end{array}$ \\
\hline $\mathrm{YBaCo}_{3} \mathrm{ZnO}_{7+\delta}$ & $700{ }^{\circ} \mathrm{C}$ & 1.68 & 0.17 & $\begin{array}{l}1.25 \\
\text { E-3 }\end{array}$ & 0.86 & 0.17 & $9 \mathrm{E}-2$ & 0.5 & & & & & & $\begin{array}{l}2.5 \\
\text { E-3 }\end{array}$ \\
\hline $\mathrm{Y}_{0.9} \mathrm{In}_{0.1} \mathrm{BaCo}_{3} \mathrm{ZnO}_{7+\delta}$ & $500{ }^{\circ} \mathrm{C}$ & 9.73 & 4.43 & $\begin{array}{l}9.42 \\
\text { E-6 }\end{array}$ & 0.84 & 4.55 & $\begin{array}{l}3.31 \\
\text { E-6 }\end{array}$ & 0.9 & 2.25 & $\begin{array}{l}4.9 \\
\text { E-3 }\end{array}$ & 0.76 & 2.7 & $\begin{array}{l}1.9 \\
\text { E-2 }\end{array}$ & $\begin{array}{r}0.915 .0 \\
\text { E-3 }\end{array}$ \\
\hline $\mathrm{Y}_{0.9} \mathrm{In}_{0.1} \mathrm{BaCo}_{3} \mathrm{ZnO}_{7+\delta}$ & $550^{\circ} \mathrm{C}$ & 5.43 & 1.37 & $\begin{array}{l}6.19 \\
\text { E-6 }\end{array}$ & 0.9 & 1.61 & $\begin{array}{l}4.49 \\
\text { E-6 }\end{array}$ & 0.91 & 1.11 & $\begin{array}{l}3.3 \\
\text { E-3 }\end{array}$ & 0.75 & 1.3 & $\begin{array}{l}1.0 \\
\text { E-2 }\end{array}$ & $\begin{array}{r}0.866 .0 \\
\text { E-3 } \\
\end{array}$ \\
\hline $\mathrm{Y}_{0.9} \mathrm{In}_{0.1} \mathrm{BaCo}_{3} \mathrm{ZnO}_{7+\delta}$ & $600{ }^{\circ} \mathrm{C}$ & 3.81 & 0.69 & $\begin{array}{l}5.88 \\
\text { E-5 }\end{array}$ & 0.77 & 2.0 & $\begin{array}{l}2.3 \\
\text { E-3 }\end{array}$ & 0.9 & 0.68 & $\begin{array}{l}6.9 \\
E-3 \\
\end{array}$ & 0.8 & 0.44 & $\begin{array}{l}3.6 \\
\text { E-2 }\end{array}$ & $\begin{array}{r}0.55 .3 \\
\text { E-3 } \\
\end{array}$ \\
\hline $\mathrm{Y}_{0.9} \mathrm{In}_{0.1} \mathrm{BaCo}_{3} \mathrm{ZnO}_{7+\delta}$ & $650{ }^{\circ} \mathrm{C}$ & 2.64 & 0.36 & $\begin{array}{l}2.6 \\
\text { E-3 }\end{array}$ & 0.75 & 0.37 & $\begin{array}{l}1.9 \\
\text { E-2 }\end{array}$ & 0.64 & & & & & & $\begin{array}{l}7.7 \\
\text { E-4 }\end{array}$ \\
\hline $\mathrm{Y}_{0.9} \mathrm{In}_{0.1} \mathrm{BaCo}_{3} \mathrm{ZnO}_{7+\delta}$ & $700{ }^{\circ} \mathrm{C}$ & 1.75 & 0.19 & $\begin{array}{l}1.3 \\
\text { E-3 }\end{array}$ & 0.84 & 0.19 & $\begin{array}{l}8.0 \\
\text { E-2 }\end{array}$ & 0.5 & & & & & & $\begin{array}{r}1.5 \\
\text { E-3 } \\
\end{array}$ \\
\hline $\mathrm{Y}_{0.9} \mathrm{In}_{0.1} \mathrm{BaCo}_{3} \mathrm{Zn}_{0.6} \mathrm{Fe}_{0.4} \mathrm{O}_{7+\delta}$ & $500{ }^{\circ} \mathrm{C}$ & 9.64 & 4.01 & $\begin{array}{l}9.21 \\
\text { E-6 }\end{array}$ & 0.84 & 4.55 & $\begin{array}{l}3.43 \\
\text { E-6 }\end{array}$ & 0.9 & 1.17 & $\begin{array}{l}7.7 \\
\text { E-3 }\end{array}$ & 0.76 & 2.7 & $\begin{array}{l}4.5 \\
\text { E-2 }\end{array}$ & $\begin{array}{r}0.797 .5 \\
\text { E-3 }\end{array}$ \\
\hline $\mathrm{Y}_{0.9} \mathrm{In}_{0.1} \mathrm{BaCo}_{3} \mathrm{Zn}_{0.6} \mathrm{Fe}_{0.4} \mathrm{O}_{7+\delta}$ & $550{ }^{\circ} \mathrm{C}$ & 5.59 & 1.68 & $\begin{array}{l}5.02 \\
\text { E-6 }\end{array}$ & 0.9 & 1.05 & $\begin{array}{l}7.98 \\
\text { E-6 }\end{array}$ & 0.9 & 0.82 & $\begin{array}{l}1.4 \\
\text { E-2 }\end{array}$ & 0.65 & 1.02 & $\begin{array}{l}4.0 \\
\text { E-2 }\end{array}$ & $\begin{array}{rr}0.85 .4 \\
\text { E-3 } \\
\end{array}$ \\
\hline $\mathrm{Y}_{0.9} \mathrm{In}_{0.1} \mathrm{BaCo}_{3} \mathrm{Zn}_{0.6} \mathrm{Fe}_{0.4} \mathrm{O}_{7+\delta}$ & $600{ }^{\circ} \mathrm{C}$ & 3.89 & 0.22 & $\begin{array}{l}3.87 \\
\text { E-5 }\end{array}$ & 0.91 & 0.33 & $\begin{array}{l}4.0 \\
\text { E-3 }\end{array}$ & 0.5 & 0.32 & $\begin{array}{l}1.6 \\
\text { E-2 }\end{array}$ & 0.9 & 0.55 & $\begin{array}{l}6.0 \\
\text { E-2 }\end{array}$ & $\begin{array}{rr}0.53 .3 \\
\text { E-3 }\end{array}$ \\
\hline $\mathrm{Y}_{0.9} \mathrm{In}_{0.1} \mathrm{BaCo}_{3} \mathrm{Zn}_{0.6} \mathrm{Fe}_{0.4} \mathrm{O}_{7+\delta}$ & $650{ }^{\circ} \mathrm{C}$ & 2.55 & 0.26 & $\begin{array}{l}1.1 \\
\text { E-2 }\end{array}$ & 0.69 & 0.26 & $\begin{array}{l}1.1 \\
\text { E-1 }\end{array}$ & 0.58 & & & & & & $\begin{array}{l}3.8 \\
\text { E-4 }\end{array}$ \\
\hline $\mathrm{Y}_{0.9} \mathrm{In}_{0.1} \mathrm{BaCo}_{3} \mathrm{Zn}_{0.6} \mathrm{Fe}_{0.4} \mathrm{O}_{7+\delta}$ & $700{ }^{\circ} \mathrm{C}$ & 1.69 & 0.14 & $\begin{array}{l}7.5 \\
\text { E-3 }\end{array}$ & 0.74 & 0.14 & $\begin{array}{l}1.8 \\
\text { E-1 }\end{array}$ & 0.57 & & & & & & $\begin{array}{l}7.6 \\
\text { E-4 }\end{array}$ \\
\hline
\end{tabular}




\section{Figure Caption}

Fig. 1 Comparison of the isotropic thermal expansion coefficients (TEC) of the investigated $\mathrm{YBaCo}_{3} \mathrm{ZnO}_{7+\delta} \quad(\mathrm{YBCZ}), \quad \mathrm{Y}_{0.9} \mathrm{In}_{0.1} \mathrm{BaCo}_{3} \mathrm{ZnO}_{7+\delta} \quad(\mathrm{YIBCZ})$, and $\mathrm{Y}_{0.9} \mathrm{In}_{0.1} \mathrm{BaCo}_{3} \mathrm{Zn}_{0.6} \mathrm{Fe}_{0.4} \mathrm{O}_{7+\delta}$ (YIBCZF) cathodes with other known oxide-ion electrolytes and cathodes.

Fig. 2 Joint synchrotron $\mathrm{X}$-ray and neutron Rietveld refinement of (a) $\mathrm{YBaCo}_{3} \mathrm{ZnO}_{7+\delta}$, (b) $\mathrm{Y}_{0.9} \mathrm{In}_{0.1} \mathrm{BaCo}_{3} \mathrm{ZnO}_{7+\delta}$, and (c) $\mathrm{Y}_{0.9} \mathrm{In}_{0.1} \mathrm{BaCo}_{3} \mathrm{Zn}_{0.6} \mathrm{Fe}_{0.4} \mathrm{O}_{7+\delta}$ at $25{ }^{\circ} \mathrm{C}$. For a comparison, the selected area electron diffraction images of (d) $\mathrm{YBaCo}_{3} \mathrm{ZnO}_{7+\delta}$, (e) $\mathrm{Y}_{0.9} \mathrm{In}_{0.1} \mathrm{BaCo}_{3} \mathrm{ZnO}_{7+\delta}$, and (f) $\mathrm{Y}_{0.9} \mathrm{In}_{0.1} \mathrm{BaCo}_{3} \mathrm{Zn}_{0.6} \mathrm{Fe}_{0.4} \mathrm{O}_{7+\delta}$ are also shown.

Fig. 3 Variations of the cell parameters of (a) $\mathrm{YBaCo}_{3} \mathrm{ZnO}_{7+\delta}$, (b) $\mathrm{Y}_{0.9} \mathrm{In}_{0.1} \mathrm{BaCo}_{3} \mathrm{ZnO}_{7+\delta}$, and (c) $\mathrm{Y}_{0.9} \mathrm{In}_{0.1} \mathrm{BaCo}_{3} \mathrm{Zn}_{0.6} \mathrm{Fe}_{0.4} \mathrm{O}_{7+\delta}$ with temperature in air.

Fig. 4 Bulk thermal expansion coefficient of $\mathrm{YBaCo}_{3} \mathrm{ZnO}_{7+\delta}$, (b) $\mathrm{Y}_{0.9} \mathrm{In}_{0.1} \mathrm{BaCo}_{3} \mathrm{ZnO}_{7+\delta}$, and (c) $\mathrm{Y}_{0.9} \mathrm{In}_{0.1} \mathrm{BaCO}_{3} \mathrm{Zn}_{0.6} \mathrm{Fe}_{0.4} \mathrm{O}_{7+\delta}$ as a function of temperature.

Fig. 5 Thermogravimetric analysis (TGA) analysis of $\mathrm{YBaCo}_{3} \mathrm{ZnO}_{7+\delta}$, (b) $\mathrm{Y}_{0.9} \mathrm{In}_{0.1} \mathrm{BaCo}_{3} \mathrm{ZnO}_{7+\delta}$, and (c) $\mathrm{Y}_{0.9} \mathrm{In}_{0.1} \mathrm{BaCo}_{3} \mathrm{Zn}_{0.6} \mathrm{Fe}_{0.4} \mathrm{O}_{7+\delta}$.

Fig. 6 Bond valence sum map of $\mathrm{YBaCo}_{3} \mathrm{ZnO}_{7+\delta}$. $\mathrm{Ba}, \mathrm{Ca}$, $\mathrm{Co}$ and $\mathrm{O}$ ions are labelled, respectively, as purple, orange, blue, and red. The light purple contour (u.v. $=0.05$ ) shows the interstitial oxide-ion location/pathway around the $\mathrm{Ba} / \mathrm{Ca}$ ions and $\mathrm{CoO}_{4}$ polyhedra. The cross section of (110) at $\mathrm{z}=1 / 2$ shows the location of disordered interstitial oxide ions around the $\mathrm{Ba}$ and $\mathrm{Y}$ ions.

Fig. 7 Comparison of the change in the $\mathrm{Co}-\mathrm{O}$ bond length in $\mathrm{YBaCo}_{3} \mathrm{ZnO}_{7+\delta}, \mathrm{Y}_{0.9} \mathrm{In}_{0.1} \mathrm{Co}_{3} \mathrm{ZnO}_{7+\delta}$, and $\mathrm{Y}_{0.9} \mathrm{In}_{0.1} \mathrm{Co}_{3} \mathrm{Zn}_{0.6} \mathrm{Fe}_{0.4} \mathrm{O}_{7+\delta}$ as a function of temperature.

Fig. 8 (a) Impedance spectroscopy of the symmetric cells for $\mathrm{YBaCo}_{3} \mathrm{ZnO}_{7+\delta}$, $\mathrm{Y}_{0.9} \mathrm{In}_{0.1} \mathrm{BaCo}_{3} \mathrm{ZnO}_{7+\delta}$, and $\mathrm{Y}_{0.9} \mathrm{In}_{0.1} \mathrm{BaCo}_{3} \mathrm{Zn}_{0.6} \mathrm{Fe}_{0.4} \mathrm{O}_{7+\delta}$ at $700{ }^{\circ} \mathrm{C}$ in air. (b) The Arrhenius plots of the polarization resistance of $\mathrm{YBaCo}_{3} \mathrm{ZnO}_{7+\delta}, \quad \mathrm{Y}_{0.9} \mathrm{In}_{0.1} \mathrm{BaCo}_{3} \mathrm{ZnO}_{7+\delta}$, and $\mathrm{Y}_{0.9} \mathrm{In}_{0.1} \mathrm{BaCo}_{3} \mathrm{Zn}_{0.6} \mathrm{Fe}_{0.4} \mathrm{O}_{7+\delta}$ in air. 
Figures

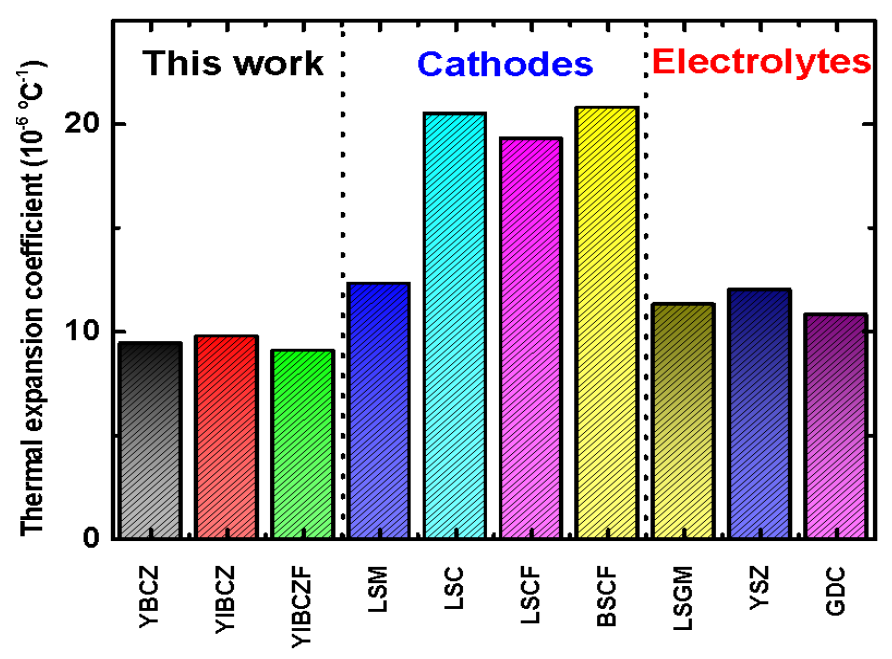

Fig. 1 

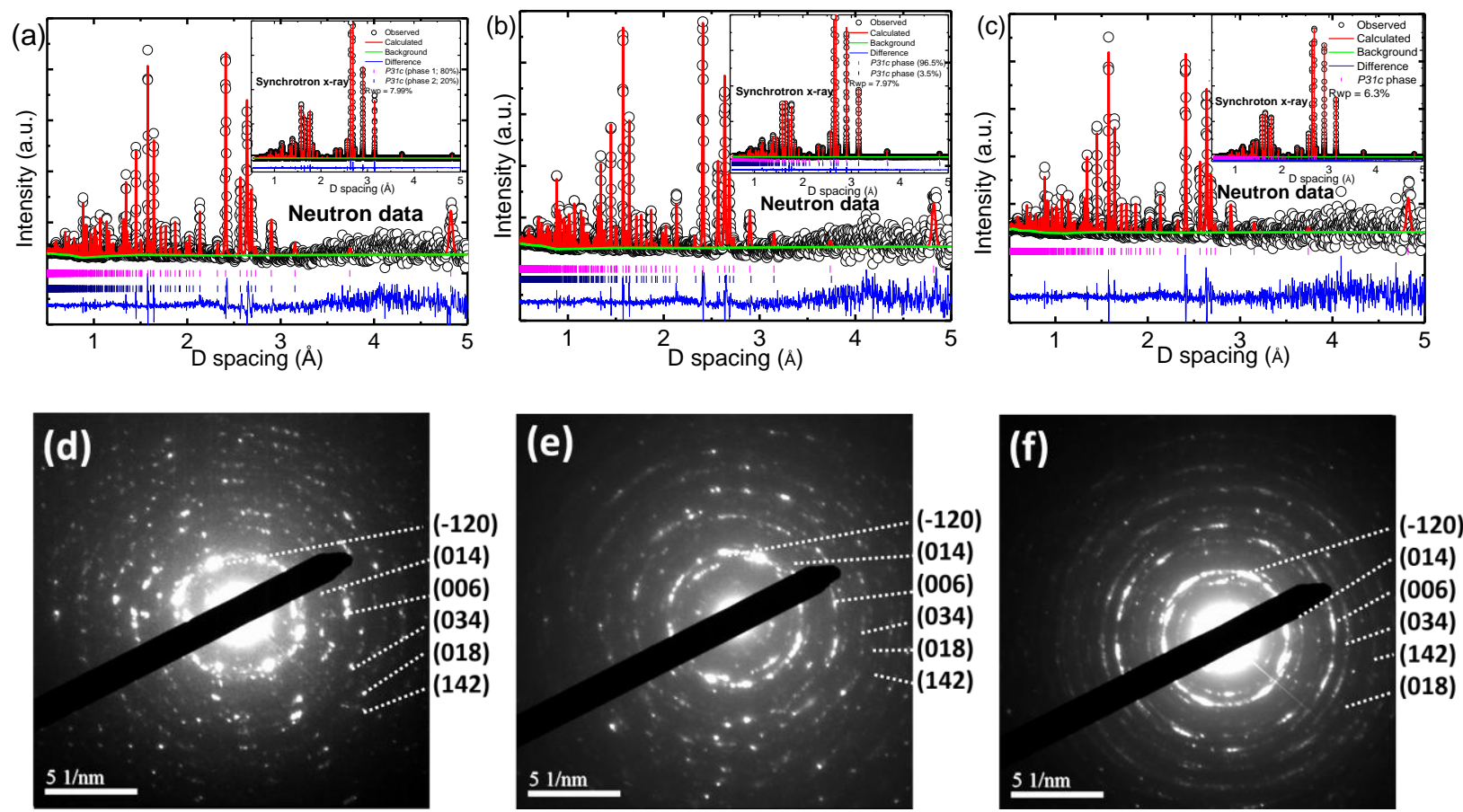

Fig. 2 

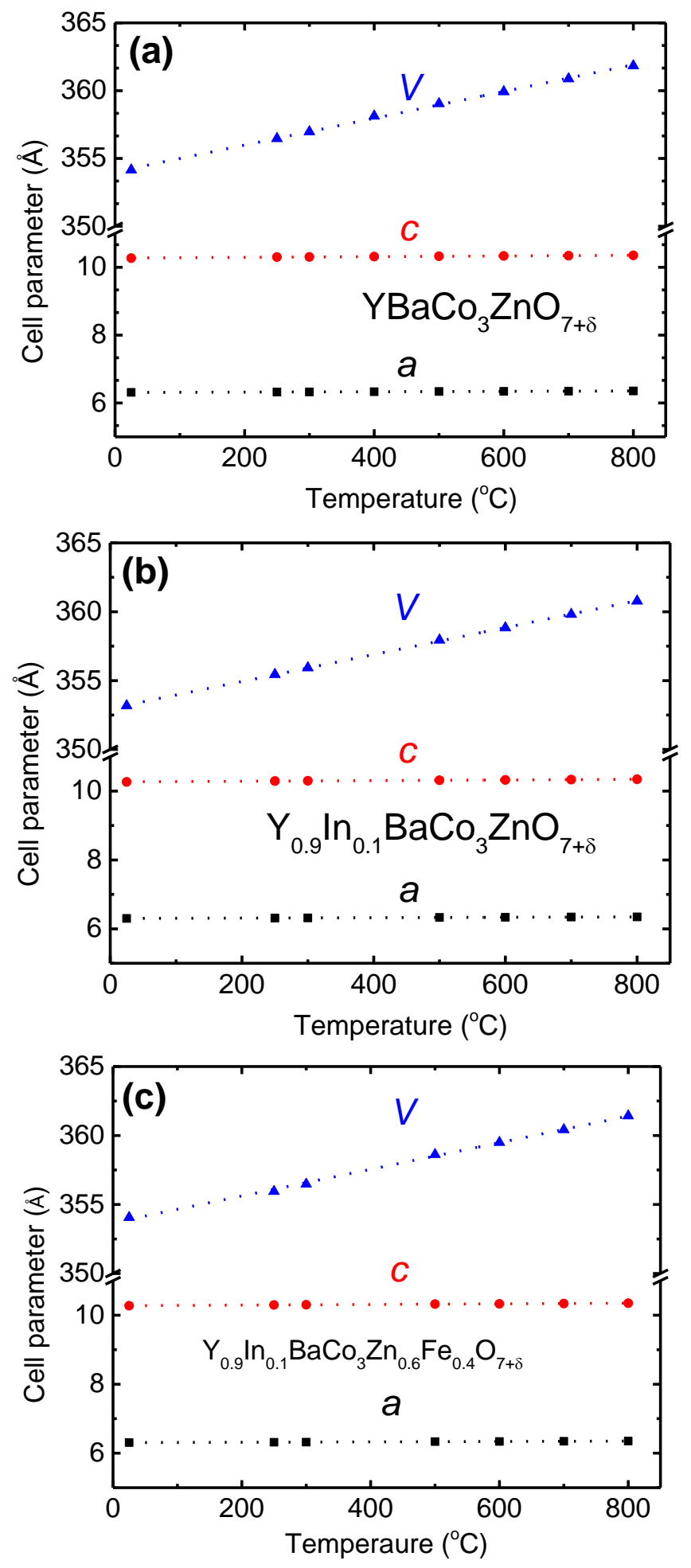

Fig. 3 


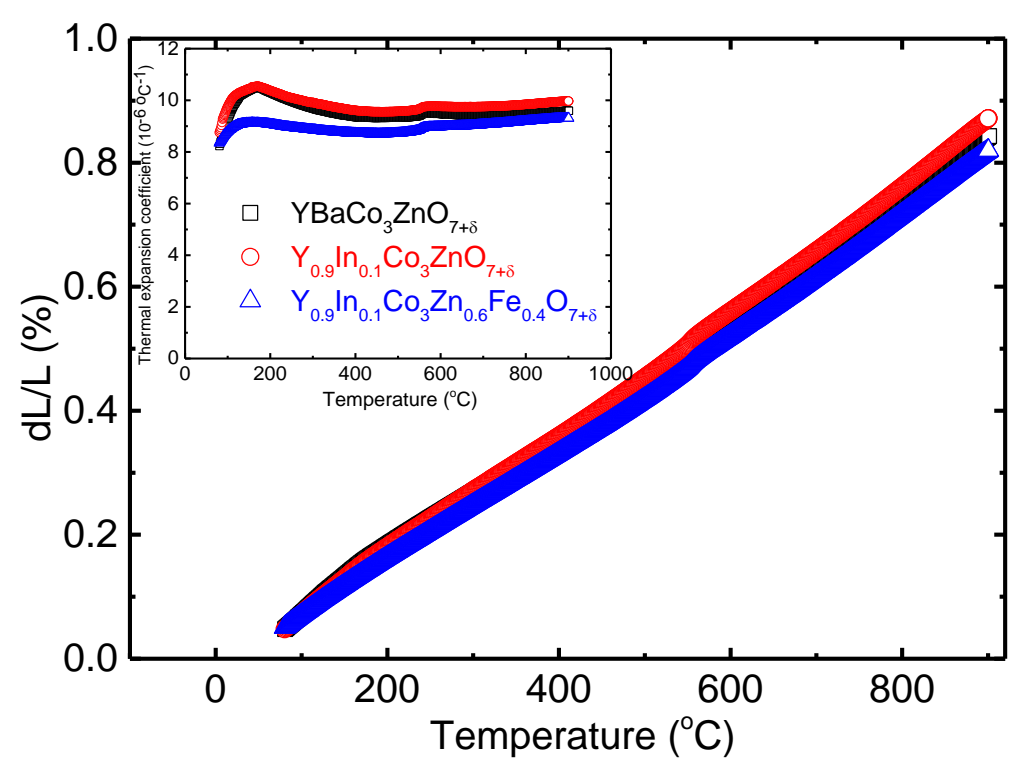

Fig. 4 


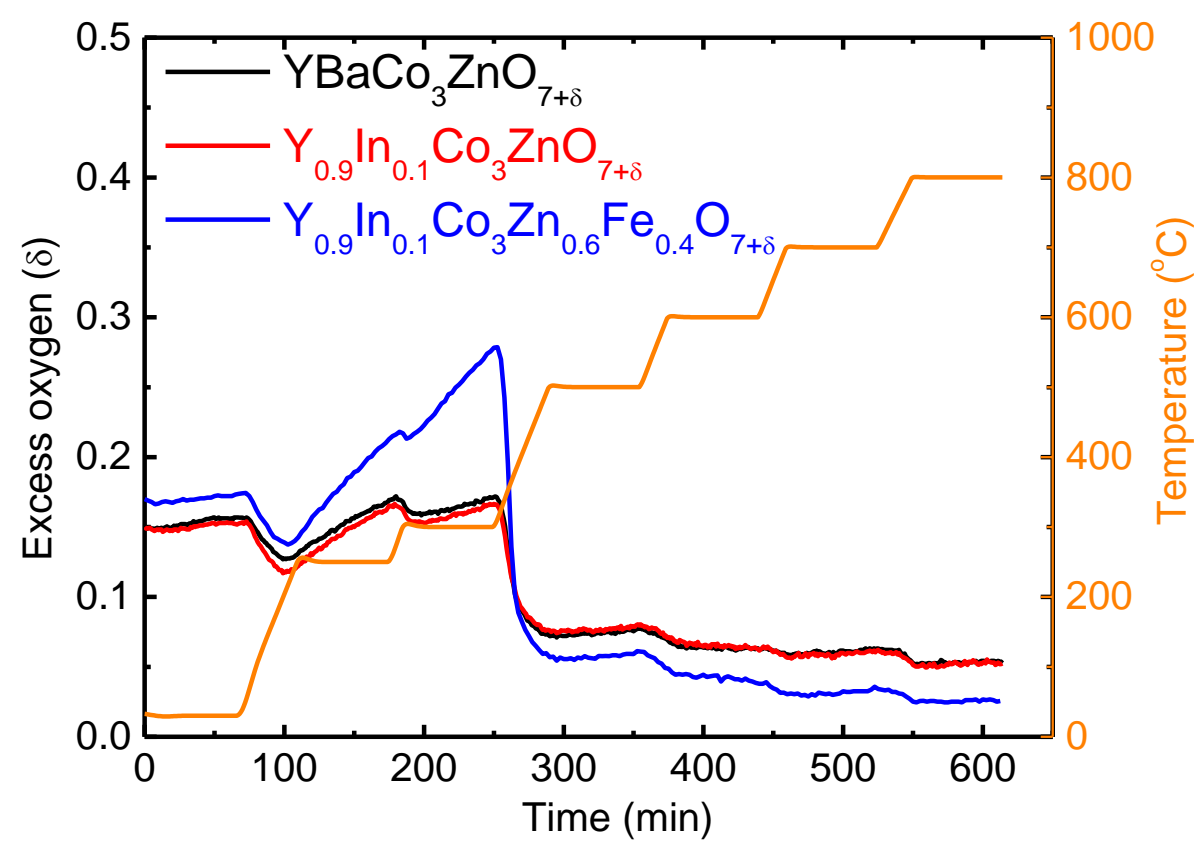

Fig. 5 


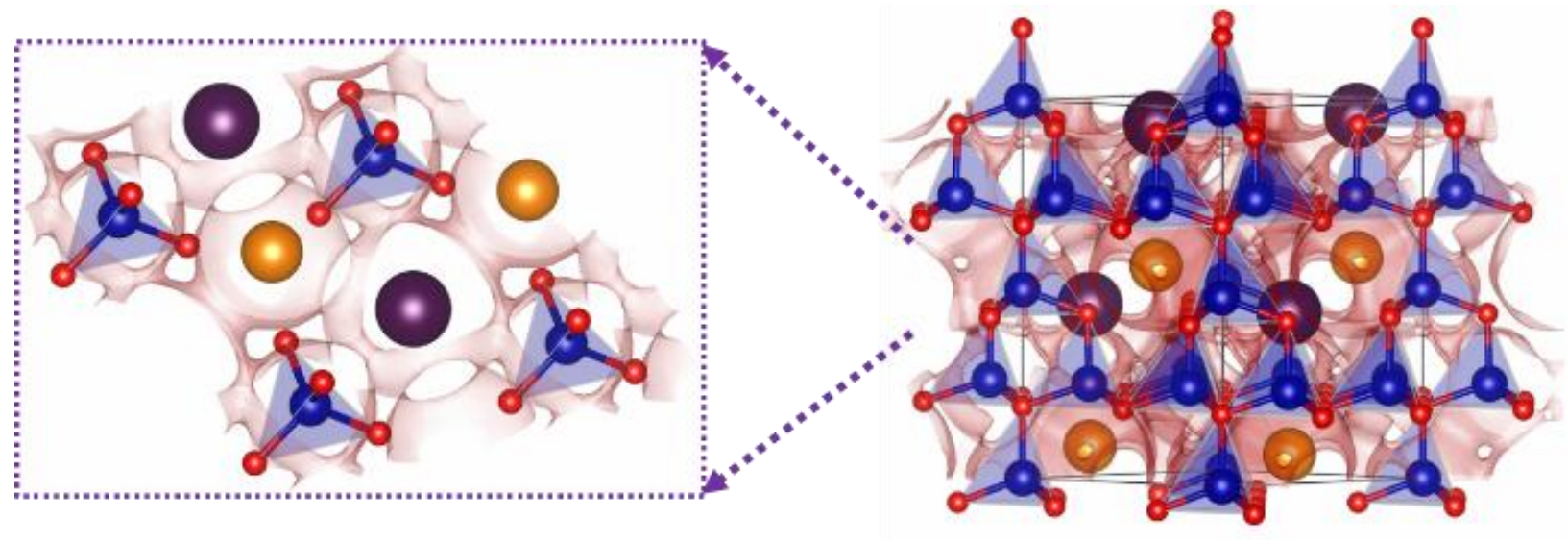

Fig. 6 


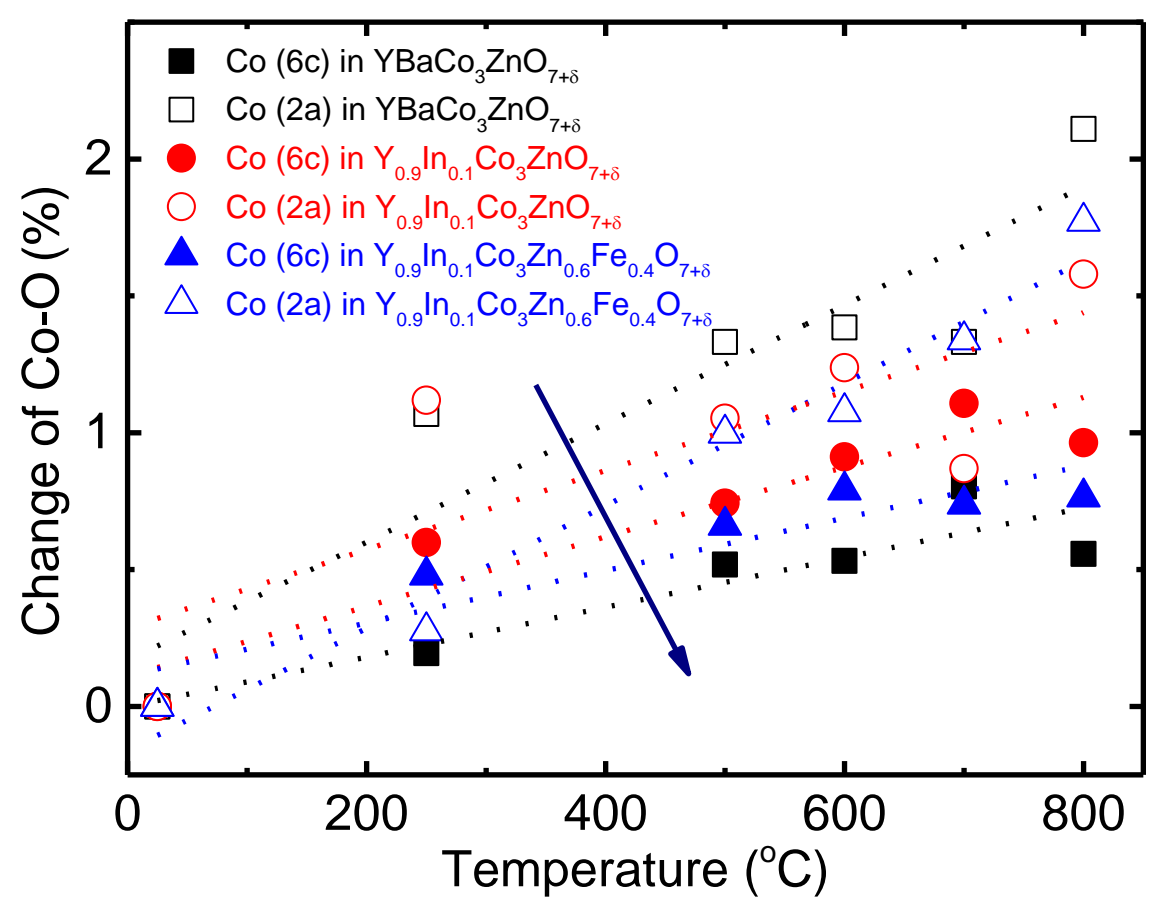

Fig. 7 

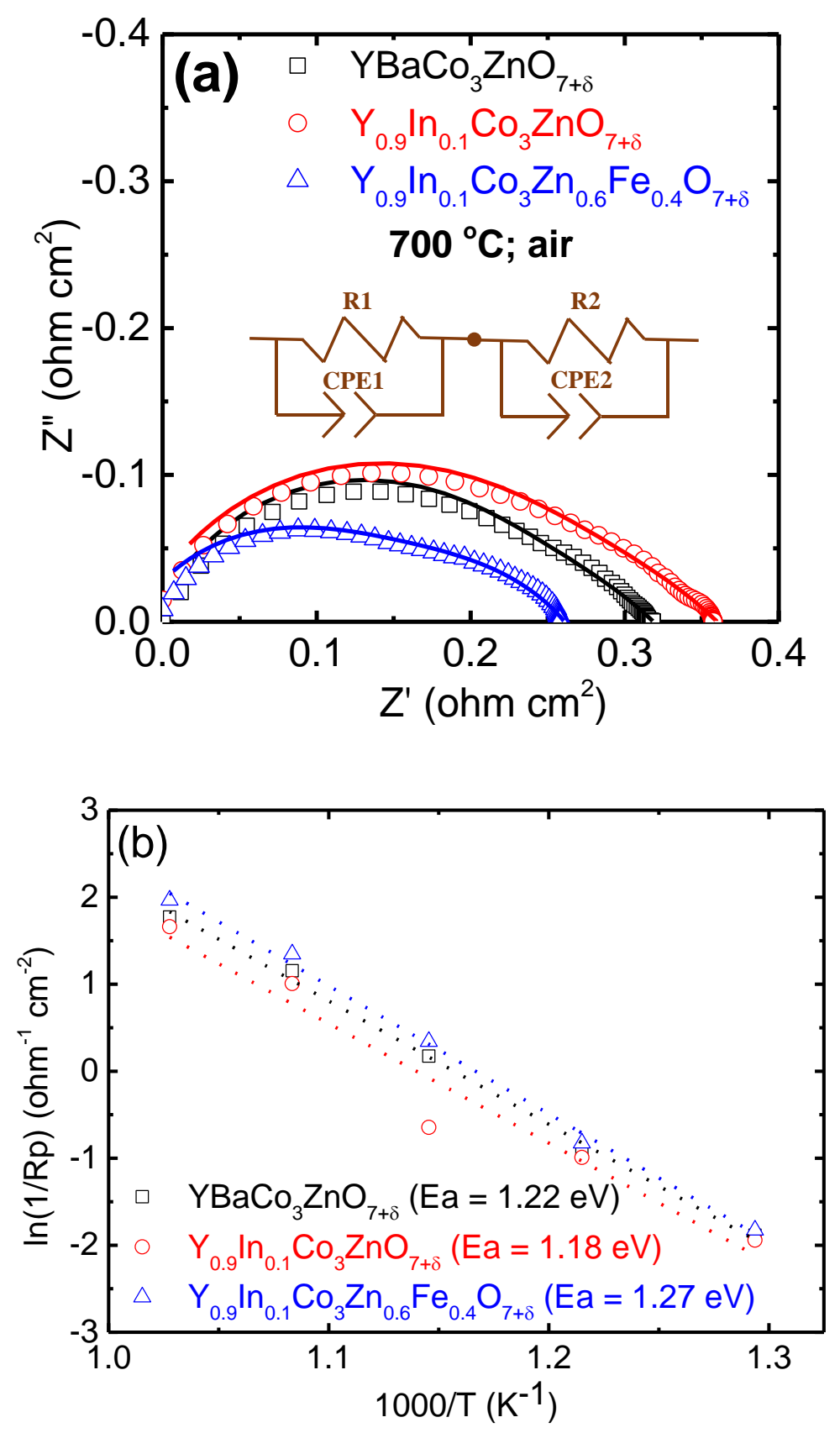

Fig. 8 